\title{
Does Financial Liberalization and Investment Rate Affect Financial Development in Cameroon?
}

\author{
Victalice Achamoh Ngimanang ${ }^{1} \&$ Ibrahim $_{\text {Ngouhouo }}{ }^{1}$ \\ ${ }^{1}$ Faculty of Economics and Management, University of Dschang, Cameroon \\ Correspondence: David Wolf II, School of Management, Northern Canada University, Toronto, ON., M3A 2K7, \\ Canada. Tel: 1-613-947-3592. E-mail: davidwolf@gc.ca
}

Received: October 5, 2015

Accepted: December 21, $2015 \quad$ Online Published: January 25, 2015

doi:10.5539/ijef.v8n2p136

URL: http://dx.doi.org/10.5539/ijef.v8n2p136

\begin{abstract}
This study investigates the key determining factors of financial development using Cameroons time series data from 1977 to 2010. After over-viewing the financial market and financial development in Cameroon and exploring some relevant literature, the study specifies and estimates long- and short-run functions for financial development using co-integration and error correction techniques. Financial liberalization, Gross investment rate, GDP growth rate, inflation rate and government spending appear to significantly influence the level of credit to the private sector in Cameroon. Gross investment rate significantly promotes financial development in the longand short run whereas financial liberalization significantly contributes to private credit only in the short run. These results suggest that the efficiency of the financial sector in allocating credit to the private sector could be enhanced by encouraging gross investment in the short and long run and equally by liberalising the financial sector in the short run.
\end{abstract}

Keywords: financial development, cointegration, causality, Cameroon

\section{Introduction}

Economists' understanding of the role of financial system as a driver of economic growth has evolved considerably in recent years. The role of finance was neglected in early literature on development. Amongst the pioneer studies on whether finance exerts a causal influence on growth, Bagehot (1873) found that financial markets facilitate the accumulation of capital and manage risk inherent in investment projects and industries. Financial services stimulate innovation and growth (Schumpeter, 1911), respond to the needs of the real economy (Robinson, 1952) and equally play a crucial role in the process of economic development (Engerman \& Sokoloff, 1996). In general, financial functions lower transaction costs between savers and borrowers and thus contribute to the process of capital accumulation, technological innovations and hence economic growth (King \& Levine, 1993).

The relationship between financial development and economic growth was extensively analysed more than three decades ago by Goldsmith (1969), McKinnon (1973), Shaw (1973) and others. They found strong and positive correlations between the level of financial market development and the rate of economic growth. More comprehensive empirical research was undertaken by King and Levine (1993) who confirmed a very strong relationship between each of their four financial development indicators and economic growth.

Unlike the supply-leading hypothesis (Patrick, 1966; McKinnon, 1973; Jung, 1986; King \& Levine, 1993; Levine et al., 2000) which posits a causal relationship from financial development to economic growth, demand-leading hypothesis postulates a unidirectional causality instead from economic growth to financial development (Goldsmith, 1969; Odhiambo, 2007).

Studies focusing exclusively on developing countries such as Luintel and Khan (1999), and that of Odhiambo (2007) were in line with the demand-following hypothesis that, a significant unidirectional causality instead runs from growth to finance. Odedokun (1996) however found mixed results. Jung (1986) (Note 1) concluded from the experience of fifty six countries between 1950 and 1980 using time series analysis that finance causes growth more frequently in developing countries and growth causes finance mostly in industrialized countries. The result is however country specific and tend to vary with the proxies used in measuring financial development (Jung, 1986, Yousif, 2002). 
Recently, the attention of most researchers has extended from finance-growth nexus to the examination of other important correlates of financial development. In this regard, openness to external trade is widely noted to boost the level of financial development (Do \& Levchenko, 2004; Huang \& Temple, 2005), and financial liberalization (Note 2) equally fosters financial development (World Bank; 1989, Tabi, Njong, \& Neba, 2011). The level of gross investment significantly contributes to financial development among other factors such as per capita income, literacy rates, inflation, and cultural or religious forces (Seetanah et al., 2011).

Majority of studies have established a positive link between financial development and economic growth. A bulk of this research is concentrated mainly on developed countries with scarce amount of work based exclusively on developing countries. There are very few studies on the finance-growth debates devoted exclusively on Cameroon's data (Tabi, Njong, \& Neba, 2011). For studies on causes of financial development, we have not come across any rigorous research on the determinants of financial development using Cameroon data.

The economy of Cameroon has witnessed a remarkable evolution in its financial sector just as the country itself has evolved in its economic and political structure. The traditional banking sector, like the non-banking establishments has experienced dynamic changes during the past decades driven by advances in information and communications technology and widespread reductions in international barriers to trade and investment that have facilitated the movement of money into a global activity.

The financial market of Cameroon as of 2010 comprised of eleven commercial banks, eleven non-banking financial establishments, over 1000micro-finance institutions (Note 3) and an increasing number of foreign exchange bureaus. In spite of this large number, the granting of credit, excluding bad loans, is far below the minimum annual rate of 30 percent needed to satisfy the country's financing requirements (BEAC, 2010). The financing deficit of the economy alongside recent excess liquidity reported in the banking system is a call for concern.

Based on the IMF (2010) data for Cameroon, the ratio of private credit to GDP used as a proxy for financial development rose from the average of 20.03 percent in the 1970s to 27.1 percent in the 1980s and later fell to 12.4 percent in the 1990s. The ratio further deteriorated to barely 9.4 percent on average between 2000 and 2010 . Investment rate with similar trend except for the last decade rose from 20.4 percent in the 1970s to the average of 24.62 percent in the 1980s. The rate fell sharply to barely 16.8 percent on average in the 1990s and rose negligibly by 0.7 percent in the subsequent decade. The low ratio of domestic credit to GDP partly motivates us to investigate the various determinants of financial development measured in terms of credit to the private sector. In doing this, emphasis is placed on the role of financial liberalisation as Cameroon has a rich history of financial reforms, a country that has witnessed both financial repression and financial liberalisation policies.

Coupled with this situation, the world economy has recently witnessed another severe financial crisis, during the period 2007-2009 (Huang, 2010; and Bruno, 2010), the issues surrounding the emergence, development of financial markets and finance-growth nexus is becoming an increasingly significant area for research and debate worldwide. As noticed earlier, a good number of studies in this domain concentrate on finance-growth links in developed countries with controversial results. In addition, the recent worldwide financial crisis is said to have greatly affected the financial sector of developing countries than those of developed nations who provoked the crises (Bruno, 2010; Bernanke, 2010). Cameroon's financial market was not spared by the crisis as private credit ratio fell to 9.1 percent in 2009 (below the relatively very low period average of 9.4\%) before picked up slowly in the subsequent years.

In the face of the low private credit to GDP ratio taken as an indicator of financial development, one is faced with a key question: what major factors influence the level of financial development of a developing country like Cameroon?

The objective of this paper is therefore to identify the main determinants of financial development in Cameroon. The following research hypotheses emanate from this objective, assuming other things constant:

- The level of investment is complementary to the rate of financial development.

- Financial liberalization correlates more with financial development relative to other regressors.

The remainder of the paper is organized as follows: Section 2 gives an overview of Cameroon's financial development; in Section 3, we review the relevant literature before concentrating on the empirical methodology in Section 4. Section 5 presents and discusses the empirical results, followed by the conclusion in Section 6.

\section{An Overview of Financial Development in Cameroon}

The financial sector of Cameroon during the post-independence period (1960 to 1985) developed under the umbrella of monetary and regulatory policies aimed at supporting the state-orchestrated development strategies. 
The financial sector became an instrument of planned industrialization policies and operated under a framework characterized by controlled interest rates, directed credit programs, high reserve requirements and other restrictions on financial intermediation as well as restricted entry into the market (Tabi, Njong, \& Neba, 2011). This situation has been termed financial repression by the proponents of financial liberalization. All banks were owned by the state and credits were directed to sectors deemed important.

By 1987, due to the down turn in the global economy, the demand and the prices of the main exports of Cameroon declined. At this time also, the real exchange rate of the franc appreciated sharply, while the US dollar depreciated by 40 percent against the CFA and the terms of trade deteriorated by 47 percent. Oil output also started declining (Amin, 2002). All these let to a drastic collapse of the economy after practically two decades of good performance. The decline in GDP was sudden and drastic from 8 percent to -5 percent within the space of one year (Amin, 2002).

The financial sector was not spared by the crisis in the real sector. The collapse of the real sector made companies not to meet their financial obligations. This coupled with other factors such as the incompetence of managers, poor management techniques, competition from the informal financial sector, and state intervention let to serious crises in this sector (Wamba, 2001). Many banks went bankrupt and others became illiquid and unable to meet the withdrawals of depositors. Under the structural adjustment programs, the restructuring of the financial sector was undertaken in which some banks were liquidated (Tabi, Njong, \& Achamoh, 2012).

There was also a change in monetary and financial policies with the liberalization of financial markets in 1990. A new banking regulatory agency (COBAC) was also established. As such, there was the deregulation of interest rates, the removal of directed credit schemes, and the privatisation of banks coupled with the creation of the Douala Stock Exchange that has remained in an embryo state. It was believed that such a system could better support an economy that will henceforth be regulated by market forces. These reforms marked the end of a Keynesian inspired plannified economy and repressed financial system and the beginning of a classical market based system. With all the above reforms, the economy regained the path of economic growth and the banking sector regained its liquidity and soundness.

The second half of the 1990s was marked with encouraging results in banking performance. Majority of the banks registered an upturn in their activities. The banking institutions regained their liquidity and profitability after many years of hardships. Interestingly, the encouraging performances of the banking institutions though coupled with other factors motivated the entry of four new banks into the Cameroonian financial market (Tabi et al., 2012). These banks included commercial bank of Cameroon (CBC), Citibank Cameroon, Union Bank of Cameroon (UBC) and ECOBANK. The resulting number of banks rose from six recorded in 1998 to eleven by 2008. These include: BICEC, SGBC, SCB-CLC, SCBC, AFRILAND BANK, AMITY Bank, CBC, CITIBANK, UNION Bank, ECOBANK and NFCC arranged according to general volume of activity (National Credit Council, 2008).

\section{Review of Literature}

Bagehot (1873) was one of the earliest economists to write on the nature of the relationship between financial systems and economic growth and the issue has evolved significant over time. He defined two primary roles of financial markets: as institutions that facilitate the accumulation of capital and one which manage risk inherent in particular investment projects and industries. To him, finance played an important role in the industrialization of England through facilitating the accumulation of capital for large works as he ascertained that the industrial power of a country is the ability of its financial markets to mobilize savings to finance major infrastructural works.

Several prominent economists have since then conducted many empirical studies to verified carried out to investigate the finance growth nexus with mix results (Schumpeter, 1911; Robinson, 1952; King \& Levine, 1993; Luintel \& Khan, Tche, 1997, among others). Tabi, Njong and Neba (2011) used two measures of financial development (Note 4) and found that financial development positively affects economic growth in the longrun in Cameroon from 1970 to 2005. They used the cointegration techniques and did not however examine the other determinants of financial development in Cameroon.

Exploring what determines financial development has become an increasingly significant research topic in recent years. See, for instance LaPorta et al. (1997, 1998), Beck et al. (2003), Rajan and Zingales (2003), and, Stulz and Williamson (2003) to mention a few. LaPorta et al. $(1997,1998)$ have made a significant contribution to this topic concerning the legal determinants of financial development. By applying the settler mortality hypothesis of Acemoglu et al. (2001) to financial development, Beck et al. (2003) address how institutions matter for financial development. 
Stulz and Williamson (2003) illustrated that the cultural and religious force of a society strongly determines the level of financial development. As to the role of macroeconomic policy on financial development, among others, Do and Levchenko (2004) and Huang and Temple (2005) study the importance of trade openness, while Chinn and Ito (2005) focus on the effect of financial openness. Both studies found a positive relation between trade/ financial openness and the development of the financial sector. Other large bodies of research identify macroeconomic factors such as inflation, the income level (GDP per capita), financial liberalization and the saving rate as important determinants of financial development while others stress on the role institutional factors and geographic factors on financial development.

Turning to some important determinants of financial development, some recent work have supported the view that policies which encourage openness to external trade tend to boost financial development (Do \& Levchenko, 2004; Huang \& Temple, 2005). Huang and Temple (2005) use cross-country and time-series variation in openness and financial development and found a positive effect of increases in goods market openness on financial development. Huang (2005) added that, national macroeconomic policies such as maintaining lower inflation and higher investment are conducive to financial development.

Research has equally been carried out to study the effects of financial liberalization on financial development over the past three decades following the McKinnon-Shaw model (McKinnon, 1973; Shaw, 1973), which concludes that, while financial repression reduces the quantity and quality of aggregate investment, financial liberalization can foster economic growth by increasing investment and its productivity. The positive link between domestic financial liberalization and financial development is supported by evidence of World Bank (1989) though domestic financial liberalization is not without risks (Demirgüç-Kunt \& Detragiache, 1998). Research on the positive correlation between external financial liberalization, especially capital account openness, and financial development is equally discussed in the panel data studies of Chinn and Ito (2005) and Seetanah et al. (2011).

Seetanah et al. (2011) holds that financial development fosters economic growth and proceeds to investigate the determinants of financial development in Mauritius using a time series data set from 1970 to 2008, by means of the ARDL approach and using two different proxies for financial development. The results from the study reveals that trade openness and financial liberalization are important determinants of financial development. In addition, investment rate, per capita income and literacy rates are also tested as others important factors in stimulating financial development. Inflation adversely influences financial development both in the short and long run. Cultural or religious forces were found to play an insignificant role in determining financial development in a multi-cultural society like Mauritius.

Twenty years after the financial reform of 1990s in Cameroon, studies are needed to evaluate the effects of the reforms and to determine how the new financial structure affects the real sector so as to correct loop holes in policy designs. Literature on finance and growth nexus permits us to understand that countries differ in their financial structures and this implies different outcomes on their real sectors (Levine, 1997 and others). It is therefore necessary to carryout country specific studies in order to relate the findings to policy designs within specific cases.This is done by examining the determinants of financial sector development in Cameroon.

Typically, financial sector liberalization in developing countries according to Jayati (2005) has been associated with measures that are designed to make the central banks more independent, relieve "financial repression" by freeing interest rates and allowing financial innovation, and reducing directed and subsidized credit, as well as allow greater freedom in terms of external flows of capital in various forms. All these measures contribute to the efficiency with which financial sector performs its financial functions.

Particularly, there is a great need to carry out a study to assess the success of financial sector reform (financial liberalization policy) and or investment rate which has been on the rise in the last decade in Cameroon on financial development and subsequently on economic growth. This is an important case as Cameroon economy has witnessed both financial repression and financial liberalization policies. The results of the study will enrich policy makers with empirical evidence on whether financial liberalization records some success in Cameroon or not. To accomplish this task, we shall first develop a theoretical framework from which the model is specified, followed by the model estimation procedure, presentation and discussion of empirical results.

\section{Methodology}

\subsection{Econometric Model of Financial Development}

To investigate the effect of investment rate and financial liberalization on financial development in Cameroon, a model of the following general form is specified: 


$$
F D_{t}=f\left(W_{t}, Q_{t}, v_{t}\right)
$$

Where:

$\boldsymbol{F D _ { t }}$ is credit to the private sector as a ratio of GDP

$\boldsymbol{W}_{t}$ is a vector of investment rate and financial liberalisation considered as the main determining variables

$\boldsymbol{Q}_{t}$ is a set of others determining factors (openness of the economy, rate of inflation, size of the government, growth rate of GDP among others)

$\mathbf{v}_{\mathrm{t}}$ is the error term

\subsection{Specification of the Long Run Model for the Determinants of Financial Development}

To empirical investigate the relationships between financial development and its determining variables, time series data are compiled from World Development Indicators CD-ROM (2011), the IMF (2012), the International Financial Statistics- IFS CD-ROM (2010), and Statistics from the National Institute of Statistics (NIS) in Yaounde (Note 5). The following cointegration equation is specified:

$$
\log (F D)_{t}=b_{0}+b_{1} \log (I N V)_{t}+b_{2}(F L)_{t}+b_{3} \log (G O V)_{t}+b_{4} \log (O P)_{t}+b_{5}(I N F L)_{t}+b_{6}(G R)_{t}+e_{t}
$$

Where;

$\log F D$ is the Log of financial development

$\log I N V$ is the investment rate

$\log F L I$ is the Log of financial liberalization index

$\log G O V$ is the $\log$ of size of the government

$\log O P$ is the Log of openness of the economy

$I N F L$ is rate of inflation

$G R$ is the growth rate of real GDP

$e_{t}$ is the error term

\subsection{Error Correction Model of Financial Development}

To capture short run adjustments of financial development from longrun model, we specify a flexible dynamic distributed lag model which includes an error correction term from a cointegrating regression as in equation (2)

$$
\begin{gathered}
\Delta \boldsymbol{L o g}(\boldsymbol{F D})_{t}=a+\sum_{j=0}^{n 1} b_{j} \Delta \boldsymbol{L o g}(\boldsymbol{I N V})_{t-j}+\sum_{j=0}^{n 2} c_{i, j} \Delta \log (\boldsymbol{F L I})_{i, t-j}+\sum_{j=0}^{n 3} d_{i, j} \Delta \log (\boldsymbol{G O O V})_{i, t-j}+\sum_{j=0}^{n 4} m_{i, j} \\
\Delta \boldsymbol{L o g}(\boldsymbol{O P})_{i, t-j}+\sum_{j=0}^{n 5} n_{i, j} \Delta(\boldsymbol{I N F L})_{i, t-j}+\sum_{j=0}^{n 6} p_{i, j} \Delta(\boldsymbol{G R})_{i, t-j}+\sum_{j=1}^{n 7} q_{j} \Delta \log (\boldsymbol{F D})_{t-j}+\pi \hat{\boldsymbol{e}}_{t-\boldsymbol{I}}+\mu_{t}
\end{gathered}
$$

where $\hat{e}_{\mathrm{t}}$ is the predicted residual term from a co-integrating relationship estimated from the long-run model in equation (2), $\pi$ is the coefficient of the error correction term, $\Delta$ is the difference operator and $\mu_{\mathrm{t}}$ is the usual white nose. This procedure is however valid only if, at least, a co-integrating relation exists among the variables irrespective of whether there possess unit roots at level form or not. This entails testing for the significance level of the lagged residual term $\left(\widehat{e}_{t-1}\right)$ included in the ECM (equation 3). When it is significant, the variables are said to be cointegrated and error correction terms exist to account for short run deviations from the long run equilibrium relationship implied by the cointegration.

\subsection{Estimation Procedure}

Like in other empirical studies, Engle and Granger (1987) method of cointegration is used instead of Johansen (1988) method of cointegration because of the limited length of data (from 1977-2010). The method requires time series pre-testing. As such, all the variables in the model are first tested for unit roots by the Augmented Dickey-Fuller (ADF) and Phillip-Perron (PP) test to eliminate the possibility of spurious regressions. The second step consists of estimating a long-run cointegrating relationship between the variables using the cointegration-error correction framework as discussed in section 4.4.4.

We proceed from the estimation of a cointegrating long run estimate of Equation (2) to the short-run 
error-correction model (ECM) using the general-to-specific methodology. Two-step procedure is followed for estimating cointegrated error correction models. In the first step, the co-integrating regression is estimated by ordinary least squares; and the residual series (if it turns out to be stationary at level form ' $\mathrm{I}(0)^{\prime}$ ') is lagged and included among the explanatory variables in the second step to estimate the error-correction mechanism in addition to the short run dynamic model.

\section{Empirical Results and Discussion}

From the foregoing methodology, we will first present the results of unit root test, followed by the results of cointegrating regression and those of its short run dynamics counterparts (ECM). Although the model financial development as specified in equation (2) includes a good number of explanatory variables, we will lay more emphasis on the effects of financial liberalization, and gross investment rate. All the necessary calculations and manipulations are done with the help of Microsoft Excel, Eviews and STATA econometric softwares.

\subsection{Results of Unit Roots Test}

Table 1 presents the results of Philip Perron (PP) and the Augmented Dickey-Fuller (ADF) unit roots test results. The results depict that most of the variables used in the study are integrated to the order one, I(1) except the variable for growth rate and that of the rate of inflation.

Table 1. Results of unit roots

\begin{tabular}{lccccc}
\hline \multirow{2}{*}{ variables } & \multicolumn{2}{c}{ ADF unit root test } & \multicolumn{2}{c}{ PP unit root test } & \multirow{2}{*}{$\begin{array}{c}\text { Order of } \\
\text { integration }\end{array}$} \\
\cline { 2 - 5 } & Level Form & First difference & Level Form & First difference & I $(1)$ \\
\hline $\log (\mathrm{FD})_{\mathrm{t}}$ & -1.277 & $-3.332 \mathrm{~b}$ & -1.117 & $-4.279^{\mathrm{a}}$ & $\mathrm{I}(1)$ \\
$\log (\mathrm{INV})_{\mathrm{t}}$ & -2.162 & $-5.731^{\mathrm{a}}$ & -1.797 & $-7.978^{\mathrm{a}}$ & $\mathrm{I}(1)$ \\
$\log (\mathrm{GOV})_{\mathrm{t}}$ & -1.322 & $-4.101^{\mathrm{a}}$ & -0.310 & $-604^{\mathrm{a}}$ & $\mathrm{I}(0)$ \\
$(\mathrm{INFL})_{\mathrm{t}}$ & $-3.555^{\mathrm{b}}$ & -6.137 & $-3.445^{\mathrm{a}}$ & -4.780 & $\mathrm{I}(1)$ \\
$\log (\mathrm{OP})_{\mathrm{t}}$ & -1.301 & $-4.154^{\mathrm{a}}$ & -1.048 & $-5.659^{\mathrm{a}}$ & $\mathrm{I}(1)$ \\
$(\mathrm{FL})_{\mathrm{t}}$ & -1.271 & $-3.937^{\mathrm{a}}$ & -1.240 & $3.526^{\mathrm{b}}$ & $\mathrm{I}(1)$ \\
$\log (\mathrm{FLI})_{\mathrm{t}}$ & -1.301 & $-3.425^{\mathrm{b}}$ & -1.071 & -8.451 & $\mathrm{I}(0)$ \\
$(\mathrm{GR})_{\mathrm{t}}$ & $-3.90^{\mathrm{a}}$ & -7.522 & $-3.199^{\mathrm{a}}$ & & \\
\hline
\end{tabular}

Note. MacKinnon critical values at $1 \%, 5 \%$ and $10 \%$ are respectively $-3.6496,-2.9558$ and $-2.6164 .\left({ }^{\mathrm{a}}\right),\left({ }^{\mathrm{b}}\right)$ indicate variables significantly stationary at $1 \%$ and $5 \%$ levels of confidence respectively.

Source: By Author.

\subsection{Testing for the Stationarity of Error Term}

The results of cointegration regression equation of Financial Development are presented in Table 2. Estimates of Model 1 considered financial liberalisation as a dummy and Model 2 considers it as an index constructed based on six parameters. The results of unit roots test on residuals bases on the ADF test are significant at level form. The results of Phillip Perrons unit roots tests on Model 2 indicate that the model in non stationary at the level form. This indicates that the ECM of Model 2 does not exist according to Phillips Perrons test statistics as the calculated value of PP is instead greater than its critical value at the borderline (10 percent).

Table 2. Results of cointegrating regression of financial development in Cameroon

\begin{tabular}{lcc}
\hline Dependent Variable: Log of Financial development- $(\operatorname{LogFD})_{\mathrm{t}}$ & & \\
\hline Independent Variables & Model 1 & Model 2 \\
Constant & $2.150^{*}$ & $3.808^{*}$ \\
& $(1.803)$ & $(1.930)$ \\
Log of investment rate: $(\log I N V)_{\mathrm{t}}$ & $0.619^{* * *}$ & 0.332 \\
& $(2.874)$ & $(0.748)$ \\
Financial liberalisation dummy: $(\mathrm{FL})_{\mathrm{t}}$ & $-0.930^{* * *}$ & - \\
& $(-9.463)$ & $-0.413^{* * *}$ \\
Log of Financial liberalisation index: $(\operatorname{LogFLI})_{\mathrm{t}}$ & - & $(-4.395)$ \\
& & -0.127 \\
Log of government spending: $(\operatorname{LogGOV})_{\mathrm{t}}$ & $-0.322^{*}$ & $(-0.434)$ \\
\hline
\end{tabular}




\begin{tabular}{lcc}
\hline Log of the degree of openness: $(\operatorname{LogOP})_{\mathrm{t}}$ & -0.019 & -0.259 \\
& $(-0.100)$ & $(-0.871)$ \\
Rate of inflation: $(\mathrm{INFL})_{\mathrm{t}}$ & 0.002 & -0.003 \\
& $(0.354)$ & $(-0.393)$ \\
Economic growth rate: $(\mathrm{GR})_{\mathrm{t}}$ & $-0.012^{*}$ & -0.015 \\
& $(-1.784)$ & $(-1.377)$ \\
Augmented Dickey-Fuller unit root test & $-4.646 * * *$ & $-4.132^{* * * *}$ \\
Phillips-Perron unit root test & $-4.894^{* * *}$ & -2.180 \\
R-squared & 0.940 & 0.850 \\
Adjusted R-squared & 0.927 & 0.822 \\
F-statistic & $71.04(p=0.000)$ & $25.25(p=0.000)$ \\
Breusch-Godfrey LM Test & $0.957(p=0.398)$ & $14.20(p=0.040)$ \\
\hline
\end{tabular}

Note. Superscript $* * *, * * *$ indicate significance at the 1,5 , and $10 \%$ levels, respectively. Values in parentheses represent the calculated t-statistics.

Source: By Author.

There is also evidence of serial correlation of the error term in model 2 as indicated by Breusch-Godfrey LM Test and the model is not highly robust compared to model 1 . The results of both unit roots tests on the error term of Model 1 are highly significant at the level form. This is an indication that longrun relationship exists between the variables. The error terms of both models are negative and stationary at the level form following ADF unit roots tests which signify that the error correction dynamics of the models can be estimated as in Table 3.

The results of both error correction models reported in Table 3 suggest that financial development in the short run is determined by growth rate of gross domestic product, inflation rate and the first differences of financial liberalisation. First difference of gross investment rate bears the expected positive sign in both models but was only significant in a model which considers financial liberalisation as a dummy.

Table 3. Results of error correction model for financial development in Cameroon

\begin{tabular}{|c|c|c|}
\hline \multicolumn{3}{|l|}{ Dependent Variable: $\Delta(\log F D)_{t}$} \\
\hline Variables & ECM 1 & ECM 2 \\
\hline \multirow[t]{2}{*}{$\mathrm{C}$} & 0.014 & -0.050 \\
\hline & $(0.410)$ & $(-1.463)$ \\
\hline \multirow[t]{2}{*}{$\Delta(\log I N V)_{\mathrm{t}}$} & $0.332 *$ & 0.217 \\
\hline & $(1.788)$ & $(1.361)$ \\
\hline \multirow[t]{2}{*}{$\Delta(\mathrm{FL})_{\mathrm{t}}$} & $-0.473^{* * *}$ & - \\
\hline & $(-2.825)$ & \\
\hline \multirow[t]{2}{*}{$\Delta(\operatorname{LogFLI})_{\mathrm{t}-1}$} & - & $0.231 *$ \\
\hline & & $(1.763)$ \\
\hline \multirow[t]{2}{*}{$\Delta(\operatorname{LogGOV})_{\mathrm{t}-1}$} & 0.098 & -0.097 \\
\hline & $(0.459)$ & $(-0.470)$ \\
\hline \multirow[t]{2}{*}{$\Delta(\operatorname{LogOP})_{\mathrm{t}}$} & 0.324 & 0.106 \\
\hline & $(1.475)$ & $(0.534)$ \\
\hline \multirow[t]{2}{*}{$(\mathrm{GR})_{\mathrm{t}-1}$} & $0.011^{* *}$ & $0.016^{* * *}$ \\
\hline & $(2.439)$ & $(3.517)$ \\
\hline \multirow[t]{2}{*}{$(\text { INFL })_{\mathrm{t}-2}$} & $-0.011 * *$ & $-0.009 * *$ \\
\hline & $(-2.532)$ & $(-2.342)$ \\
\hline \multirow[t]{2}{*}{$(\mathrm{ECT})_{\mathrm{t}-1}$} & $-0.592 * * *$ & $-0.567 * * *$ \\
\hline & $(-3.040)$ & $(-4.347)$ \\
\hline R-squared & 0.463 & 0.583 \\
\hline Adjusted R-squared & 0.312 & 0.461 \\
\hline F-statistic & $3.076(p=0.018)$ & $4.788(P=0.002)$ \\
\hline Breusch-Godfrey LM test & $0.507(P=0.609)$ & $4.673(P=0.202)$ \\
\hline $\mathrm{ARCH}$ test for heteroscedasticity & $0.333(P=0.568)$ & $1.525(P=0.227)$ \\
\hline
\end{tabular}

Note. Superscript $* * *, * *, *$ indicate significance at the 1,5 , and $10 \%$ levels, respectively. Values in parentheses represent the calculated t-statistics.

Source: By Author. 


\subsection{Interpretation and Evaluation of Econometric Results}

The coefficient estimates for gross investment rate and that of financial liberalization in the cointegration regression results presented in Table 2 and those of the corresponding ECM estimated in Table 3 shows that there exist a long run positive relationship between the rate of investment and total credit to the private sector. A similar result is reported in Seetanah et al. (2011). This indicates that policies to encourage gross investment including both domestic and foreign direct investments could be enhanced in Cameroon to increase the efficiency of the financial sector in allocating credit to the private sector leading to financial development.

The results equally report a strong long run negative but short run positive relationship between financial liberalization and total credit to the private sector. This result tied with the general postulation in literature that financial liberalisation does not lead to higher growth in relatively low income countries in the long run because their financial systems are not sufficiently developed so as to permit significant increases in level of domestic financial credit flow.

The results equally report a negative relation between inflation rate and financial development in the short run as expected which is in line with the result of Huang (2005). It is equally noticed that growth rate of real GDP contributes to financial development in the short run but its effect is instead negative in the longrun. Our results however do not strongly support the view of Chinn and Ito (2005), Do and Levchenko (2004) and Seetanah et al. (2011) that financial openness significantly promotes financial development.

The four models reported in Table 2 and 3 are globally significant at 1 and 5 percent respectively, as indicated by their various F-statistics. The unit root test on the error correction term (ECT) is significant at 1 percent following at least one of the two tests conducted and its coefficient bears the correct negative sign, indicating that financial development is really cointegrated with its determining factors. The probability (p) of Breusch-Godfrey LM test and heteroscedasticity test indicate that there no evidence of abnormality of error and serial correlation of the successive error terms in the model and its ECM counterpart.

\subsection{Long and Short Run Dynamics and Direction of Causality between the Variables}

Short term causality is verified using the Engle and Granger causality test and the long run causality is tested by the use of Johansen and Juselius causality test.

\subsubsection{Engle and Granger Causality Test}

The test consists of rejecting the Ho hypothesis of no causality when the probability of the F-Statistics is less than 10 percent. The results of the short run causality test presented in Table 4 report the existence of one way causality from financial liberalization to financial development as the null hypothesis of no causality is rejected. No causality is noticed between investment and financial development as the null hypotheses of no causality is accepted in both directions.

Table 4. Results of short run causality test between logarithms of financial liberalization, investment rate and financial development

\begin{tabular}{lcccc}
\hline Null Hypothesis: & Obs & F-Statistic & Probability & Decision \\
\hline LogFD does not Granger Cause LogINV & 34 & 0.43380 & 0.65218 & Accept Ho \\
LogINV does not Granger Cause LogFD & & 1.94870 & 0.16067 & Accept Ho \\
LogFLI does not Granger Cause LogFD & 32 & 12.4844 & 0.00014 & Reject Ho \\
LogFD does not Granger Cause LogFLI & & 0.53576 & 0.59132 & Accept Ho \\
\hline
\end{tabular}

Source: Authors calculations.

\subsubsection{Johansen and Juselius Causality Test}

This test is employed to test the long run causality. To conduct this test, there is a need to re-examine the results of Error Correction Models (ECM) of the financial development (FD) presented earlier on Table 3. The use of these models is justified by the fact that the variables are a mixture of stationary $\mathrm{I}(0)$ and non stationary $\mathrm{I}(1)$ as noticed from the unit roots results in Table 1. Using the ECM for this test is thus, no prone to dubious results. The results indicate that, the lagged error-correction terms of ' -0.592 ' and ' -0.567 ' for the two ECMs are correctly signed, and highly significant. This is an indication that about 59 and 57 percent respectively of shocks on the financial development are corrected by the "feed-back" effect annually according to the two models (ECM 1 and 2). 


\section{Conclusion and Policy Implications}

The objective of this paper was to clarify public doubts on the extent to which the rate of investment and financial liberalization policy contribute to financial development in Cameroon. This target is achieved by estimating two-steps-least square econometric model using Cameroon's time series data from 1977 to 2010. We started by overviewing the financial market and financial development in Cameroon followed by exploring some relevant literature around the issue.

Both the cointegration test and causality tests are used to investigate the correlation between financial liberalization, gross investment rate, and financial development. It is noticed that gross investment significantly promotes financial development in the long run and short run. The effect of financial liberalization is equally very highly significant in both the short- and long run in explaining changes in credit to the private sector but negative in the long run. Results of short term causality report one-way causality from financial liberalization to financial development and not the other way round. Longrun causality test following the test of weak exogeneity reports a strong causality between these variables and financial development.

Base on the results of our research, two main suggestions aimed at fostering the development of financial sector are imperative. First, policies to encourage gross investment such as lowering the interest rate, improving on infrastructural facilities of the country, ensuring political stability, granting of subsidy or tax concession to investors could be implemented in Cameroon to increase the efficiency of the financial sector in allocating credit to the private sector leading to financial development. Second, the current financial liberalization policies undertaken should only be in encouraged in the short run. The reform policy should not be encouraged if the intention is to increase the allocation of financial resource to the private sector in the longrun as a negative and significant result is reported between the policy and private credit.

\section{References}

Acemoglu, D., Johnson, S., \& Robinson, J. (2001). Colonial origins of comparative development: An empirical investigation. American Economic Review, 91, 1369-1401. http://dx.doi.org/10.1257/aer.91.5.1369

Amin, A. A. (2002). An examination of the sources of economic growth in Cameroon. African Economic Research Consortium, Nairobi.

Bagehot, W. (1873). Lombard Street: A Description of the Money Market. London: John Murray.

BEAC. (1992, 1997, 2005, 2010). Etudes et Statistiques. Yaounde, Cameroun.

Beck, T., Demirgüç-Kunt, A., \& Levine, R. (2003). Law, endowment and finance. Journal of Financial Economics, 70, 137-181. http://dx.doi.org/10.1016/S0304-405X(03)00144-2

Bernanke, B. (2010). Causes of the recent financial crises. Before the financial crises inquiry commission, Washington DC.

Bruno, G. (2010). The Financial and Economic Crisis and Developing Countries. Revue internationale de politique de développement.

Chinn, M. D., \& Ito, H. (2005). What matters for financial development? Capital controls, institutions, and interactions. NBER working paper (11370).

Demirgüç-Kunt, A., \& Detragiache, E. (1998). Financial Liberalisation and Financial Fragility. International Monetary Fund Working Paper, WP (98/83), Washington, D.C.

Do, Q. T., \& Levchenko, A. A. (2004). Trade and financial development. World Bank Working Paper Series (3347).

Engerman, S. L., \& Sokoloff, K. L. (1996). Factor Endowments, Institutions, and Differential Paths of Growth among New World Economies: A View from Economic Historians of the United States. In S. Haber (Ed.), How Latin America Fell Behind (pp. 260-304). Stanford, Calif.: Stanford University Press.

Engle, R. F., \& Granger, C. W. J. (1987). Cointegration and Error Correction: Representation, Estimation, and Testin. Econometrica, 55, 251-276. http://dx.doi.org/10.2307/1913236

Ghirmay, T. (2004). Financial Development and Economic Growth in Sub-Saharan African Countries: Evidence from Time Series Analysis. African Development Review, 16(3), 415-432. http://dx.doi.org/10.1111/j.1017-6772.2004.00098.x

Goldsmith, R. (1969). Financial structure and development. New Haven: Yale University Press.

Huang, Y. (2005). Will political liberalisation bring about financial development? Bristol Economics Discussion 
Paper, 05(578).

Huang, Y. (2010). Determinants of Financial Development. Palgrave, Macmillan. Houndmills, Basingstoke, Hampshire, England. http://dx.doi.org/10.1057/9780230302495

Huang, Y., \& Temple, J. R. W. (2005). Does external trade promote financial development? CEPR discussion paper No. 515.

IMF. (2010). International Financial Statistics. Washington D.C.

INS. (2005, 2011). Annuaire Statistique du Cameroun. Yaounde.

Jayati, G. (2005). The Economic and Social Effects of Financial Liberalization: A Primer for Developing Countries. DESA Working Paper (4).

Jung, W. (1986). Financial development and economic growth: International evidence. Economic Development and Cultural Change, 34, 333-346. http://dx.doi.org/10.1086/451531

King, R. G., \& Levine, R. (1993). Finance and Growth: Schumpeter Might Be Right. Quarterly Journal of Economics, 108(3), 717-737. http://dx.doi.org/10.2307/2118406

Laporta, R., Lopez-de-Silanes, F., Shleifer, A., \& Vishny, R. W. (1998). Law and finance. Journal of Political Economy, 106, 1113-1155. http://dx.doi.org/10.1086/250042

Levine, R. (2001). International Financial Liberalization and Economic Growth. Review of International Economics, 9(4), 688-702. http://dx.doi.org/10.1111/1467-9396.00307

Levine, R. (1997). Financial Development and Economic Growth: Views and Agenda. Journal of Economic Literature, 25(2), 688-726.

Luintel, B., \& Khan, M. (1999). A Quantitative Reassessment of the Finance-Growth Nexus: Evidence from a Multivariate VAR. Journal of Development Economics, 60, 381-405. http://dx.doi.org/10.1016/S0304-3878(99)00045-0

McKinnon, R. I. (1973). Money and Capital in Economic Development. Washington DC: Brookings Institution.

National Credit Council. (2000, 2002 and 2008). Progress Report of Cameroon. Yaounde.

Odedokun, M. O. (1996). Alternative Econometric Approaches for Analysing the Role of the Financial Sector in Economic Growth: Time Series Evidence from LDCs. Journal of Development Economics, 50(1), 119-146. http://dx.doi.org/10.1016/0304-3878(96)00006-5

Odhiambo, N. M. (2007). Supply-leading versus Demand-following Hypothesis: Empirical Evidence from Three SSA Countries. African Development Review, 19(2), 257-280. http://dx.doi.org/10.1111/j.1467-8268.2007.00161.x

Rajan, R. G., \& Zingales, L. (1998). Financial Dependence and Growth. American Economic Review, 88, 559-586.

Robinson, J. (1952). The Rate of Interest and Other Essays, Chapter "The generalization of the general theory". London: MacMillan.

Schumpeter, J. A. (1911). The Theory of Economic Development. Cambridge MA: Harvard University Press.

Seetanah, B., Padachi, K., Hosany, J., \& Binesh, S. (2011). Determinants of Financial Development: The Case of Mauritius. Finance and Corporate Governance Conference Paper. http://dx.doi.org/10.2139/ssrn.1724404

Shaw, E. S. (1973). Financial Deepening in Economic Development. New York: Oxford University Press.

Stulz, R. M., \& Williamson, R. (2003). Culture, openness, and finance. Journal of Financial Economics, 70, 313-349. http://dx.doi.org/10.1016/S0304-405X(03)00173-9

Tabi, A. J., Njong, A. M., \& Neba, C. (2011). Financial Development and Economic Growth in Cameroon, 1970-2005. Journal of Economics and International Finance, 3(6), 367-375.

Tabi, A. J., Njong, M. A., \& Achamoh, N. V. (2012). Modeling Commercial Bank Deposits Mobilization in Cameroon. Cameroon Management Review, (24).

Tche, J. (1997). The Significance of Curb Markets in the Financial Liberalisation Debate. Unpublished Phd Thesis, Guildhall University, London.

Temple, J. (1999). The new growth evidence. Journal of Economic Literature, 37, 112-156. http://dx.doi.org/10.1257/jel.37.1.112 
Wamba, H. (2001). La Gestion Bancaire en Afrique Centrale a L'heure des Grandes Mutations; Bilan et Perspectives. Revue Gestion 2000, (6).

World Bank. (1989). World Development Report. New York: Oxford University Press.

$\mathrm{Xu}, \mathrm{Z}$. (2000). Financial development, investment, and economic growth. Economic Inquiry. http://dx.doi.org/10.1111/j.1465-7295.2000.tb00021.x

Yousif, K. A. I. Y. (2002). Financial development and economic growth: Another look at the evidence from developing countries. Review of Financial Economics, 11(2), 131-150. http://dx.doi.org/10.1016/S1058-3300(02)00039-3

\section{Notes}

Note 1. He used two measures of financial development: The ratio of M2/GDP, The ratio of currency to M1, and measure growth rate in terms of Real per capita GDP

Note 2. Seetanah, Padachi, Hosany and Binesh (2011) identified trade openness and financial liberalization as two most important determinants of financial development in Mauritius.

Note 3. COBAC survey of the year 2000 reviewed that the micro-finance institutions represented about $7 \%$ of the potential market and it granted credits representing only $4.3 \%$ of total loans made by the banking sector in spite of their large number

Note 4. Size of the financial sector (liquid liability to GDP ratio-LLI) and Bank Credit allocated to private enterprises by the financial sector (BPCRE) which is less comprehensive than the ratio of total credit to the private sector. GDP Per Capita was used to asses economic growth rate

Note 5. Absence of data for some variables at certain periods constrained us to limit the length of empirical analysis (from 1977 to 2010)

\section{Copyrights}

Copyright for this article is retained by the author(s), with first publication rights granted to the journal.

This is an open-access article distributed under the terms and conditions of the Creative Commons Attribution license (http://creativecommons.org/licenses/by/3.0/). 